\title{
COMPARATIVE PHYTOSOCIOLOGY OF TREE SINUSIAE BETWEEN CONTIGUOUS FORESTS IN DIFFERENT STAGES OF SUCCESSION
}

\author{
CAVALCANTE, A. de M. B., ${ }^{1}$ SOARES, J. J. ${ }^{2}$ and FIGUEIREDO, M. A. ${ }^{3}$ \\ ${ }^{1}$ Departamento de Geociências, Universidade Estadual do Ceará, CEP 60740-000, Fortaleza, CE, Brazil \\ ${ }^{2}$ Departamento de Botânica, Universidade Federal de São Carlos, CEP 13565-905, São Carlos, SP, Brazil \\ ${ }^{3}$ Departamento de Biologia, Universidade Federal do Ceará, CEP 60455-760, Fortaleza, CE, Brazil \\ Correspondence to: Arnóbio de Mendonça B. Cavalcante, Rua Professor Francisco Gonçalves, 75, CEP 60135-430, \\ Fortaleza, CE, Brazil, e-mail: arnobio@secrel.com.br \\ Received February 18, 1999 - Accepted January 19, 2000 - Distributed November 30, 2000
}

(With 3 figures)

\begin{abstract}
The Baturité Mountain Range, located in the State of Ceará (BRA), displays on its highest levels a vegetation viewed as a disjunction from the Atlantic Forest in the East of Brazil. Among the various attributes associated with this vegetation, the abundance of water resources and a high biodiversity have a more outstanding relevance. However, in view of the current accelerated deforestation process, those attributes may be threatened in a near future. Therefore, the present work is a comparative study with its focus on vegetal community organization (tree sinusiae) and the floristic similarity and the phytodiversity of two areas in different successive stages, preserved and deforested 24 years ago. The aim of that intent was to obtain information that could essentially shed light on the deforestation effects on tree vegetation and which could suggest scientific support regarding urgent projects of habitat reconstruction. The methodology used folowed the model utilized for rain forest, i.e. consisting of a random distribution of $10 \times 20 \mathrm{~m}$ plots surveying the living woody species with $\mathrm{DBH} \geq$ $5 \mathrm{~cm}$. The results obtained suggest that a possible new physiognomy type is emerging on the Baturite Mountain Range because of deforestation. The Myrtaceae and Mimosaceae families were the ones that contributed most significantly to species richness, being the most outstanding for Areas 1 and 2 , respectively. The deforestation which occurred in Area 2 eliminated 28 species and gave birth to a current densely distinct floristic composition.
\end{abstract}

Key words: tropical forest, phytosociology, vegetation.

\section{RESUMO}

\section{Fitossociologia comparativa da sinúsia arbórea entre florestas contíguas em diferentes estádios de sucessão}

A Serra de Baturité, CE (BRA), apresenta em seus níveis mais elevados uma vegetação considerada disjunta da Mata Atlântica do Leste do Brasil. Dentre os vários atributos associados à essa vegetação, a abundância de recursos hídricos e uma elevada biodiversidade são destacadamente mais relevantes. Contudo, com o corrente processo de desflorestamento, esses atributos podem, em um futuro próximo, estar comprometidos. Assim, o presente trabalho estudou comparativamente a organização comunitária vegetal (sinúsia arbórea), a similaridade florística e a fitodiversidade de duas áreas em estádios sucessionais diferentes, preservadas e desflorestadas há 24 anos. Pretendeu-se, dessa forma, gerar informações que essencialmente esclarecessem os efeitos do desflorestamento sobre a vegetação arbórea e fornecessem suporte científico a urgentes projetos de reconstrução de habitat. A metodologia utilizada 
seguiu o padrão utilizado para florestas tropicais úmidas, isto é, consistiu em distribuir parcelas retangulares com dimensões de $10 \times 20 \mathrm{~m}$ aleatoriamente nas áreas selecionadas e levantar as espécies lenhosas vivas em pé com DAP $\geq 5 \mathrm{~cm}$. Os resultados obtidos indicaram que uma possível nova arquitetura vegetacional esteja surgindo na Serra como decorrência do desflorestamento. As famílias Myrtaceae e Mimosaceae foram as que mais contribuíram para a riqueza específica, sendo as mais importantes para as Área 1 e 2, respectivamente. O desflorestamento ocorrido na Área 2 proporcionou 28 espécies a menos e uma composição florística atual densamente distinta.

Palavras-chave: floresta tropical, fitossociologia, vegetação.

\section{INTRODUCTION}

The native wooded vegetation cover in the State of Ceará decreased $30 \%$ in 12 years (19811993) which translates into a rate of deforestation of approximately 360,000 hectares/year. Today, $44 \%$ of the continental territory is covered by native wooded vegetation (PNUD/FAO/IBAMA/SEMACE, 1994).

The predominant vegetation is caatingas covering the semi-arid lands that occupy $92 \%$ of the State (FUNCEME, 1994). However, the matas úmidas covering only $0.69 \%$ or 102,411 hectares of the continental area of the State (PNUD/FAO/ IBAMA/SEMACE, 1994) and having great economic, social and ecological relevance, are disjoined parts of the Atlantic Forest in the east of Brazil.

Within the areas of the mata úmida, the Baturité Mountain Range stands out principally because of its water provision to various municipalities (including Fortaleza), its considerable biodiversity and because it suffers intense anthropic pressure on its forest cover.

Despite its importance, there are few scientific studies that concern this specific type of vegetation and none that study the phytosociological angle. A phytosociological study enables one to know the distribution of species in vertical and horizontal spaces as well as possible affinities between species or between groups of species, resulting in a valuable momentary evaluation of the vegetation.

Therefore an attempt was made to increase the availability of information as well as emphasize the consequences of human intervention in this phytocenose, emphasizing and comparing phytosociological data from two contiguous forest formations of different ages and histories of uses.

\section{MATERIAL AND METHODS}

\section{Site of study and areas investigated}

The study was carried out in the Baturité Mountain Range, CE (BRA), in the floresta subperenifolia tropical pluvio-nebular with the geographic coordinates $4^{\circ} 15^{\prime}$ lat. S and $38^{\circ} 55^{\prime}$ long. W.

The climatic characterization of the site includes temperature, precipitation and the water table. The monthly and yearly temperature averages vary between 19 and $22^{\circ} \mathrm{C}$, thermal range of approximately $2^{\circ} \mathrm{C}$ and maximum average temperatures of $27^{\circ} \mathrm{C}$ registered during the dry period. Precipitation is regularly distributed throughout the year with a yearly average of $1,666.3 \mathrm{~mm}$. However there is a more intense period in March-April-May and a less intense period in September-OctoberNovember. Finally, the water table or the coming and going of ground water is characterized by hydro-deficiency starting in August, with a yearly level of about $101 \mathrm{~mm}$. The yearly hydric excedent is always greater than $600 \mathrm{~mm}$ with greatest levels verified in March and April when it reaches levels over $200 \mathrm{~mm}$. However the climatic typology of the area falls into the mesothermic type, following Thornthwaite's classification (1955) apud FUNCEME (1994) or in the humid and sub-humid subdominions with three to five dry months (Nimer, 1989).

The geoenvironmental characterization involves geological, geomorphological and edaphological conditions: the geological conditions reveal that almost all the rocks have a crystalline base, with the rest constituted by small river depressions and river plains covered with alluvial deposits. The geomorphological characteristics are marked by high altitudes $(1,114 \mathrm{~m}$ - maximum altitude; 800 $\mathrm{m}$ average altitude), exhibiting crests, elongated 
ridges and interfluvial tables of different dimensions and widths, and finally the soil shows limitations to mechanization, susceptibility to erosion and dominance of podzólico vermelho amarelo e podzólico vermelho amarelo equivalente eutrófico soils (Leite \& Marques, 1998).

With respect to the vegetation and the flora, some studies (e.g., Figueiredo et al., 1995) point to the similarity between the Atlantic Forest in the east of Brazil, being considered a disjunction of the former, although with specific details due to its geographic isolation and location in a semi-arid environment.

The Area investigated 1 has an area of 13 ha in a mountainous area and is covered by dense vegetation that was constituted by trees that commonly reached a height of 20 meters with tops that wove together to form a canopy with few trees sticking out. Although they suffered from human activity with the removal of trees (cutting of trails and paths), their original characteristics in structure, physionomy and floristic composition were still preserved. The presence of tree trunks and creepers of thick diameter were observed showing abundant animal life (insects, birds, etc.) among other elements. Thus according to the classification proposed by Gubert-Filho (1993) for forest types, the vegetation present can be considered primary forest. The Area investigated 2 has an area of 2 ha and is contiguous to the first in a mountainous area. In 1974 the middle and bottom thirds of the bank were deforested and cleared for coffee plantations. With the failure of the coffee crops the area was abandoned and a secondary forest established itself. The secondary forest, grown up after the clearing of the primitive forest and finding itself within Gubert-Filho (1993) classification as Capoeirão type secondary vegetation showed itself to be visibly different when compared to the not formerly deforested upper third.

\section{Phytosociological survey}

The plot method (Mueller-Dombois \& Ellenberg, 1974) with dimensions of $10 \times 20 \mathrm{~m}$ was used. The sample sufficiency for the sample areas was deduced through the collector curves of the real order and considering the time-effortcost trinomial, as well as the discharacterization of the previously required physionomical homogeneity. Thus, 30 and 15 plots were randomly plotted respectively in Areas 1 and 2, showing all the live woody vegetables standing whose tops were at the level of the neck situated at the interior of the plot and which presented $\mathrm{DBH} \geq 5 \mathrm{~cm}$. Individuals that were touching the plastic tape (limit of the plot) were included on only two sides of the plot (one large and one small) and were not included on the other two sides, avoiding an overestimate of the sample. Creepers and dead individuals were not included in the selection. All sample individuals following established criteria were tagged, numbered in order of growth, independent of the numbering of the plots and recorded with the following data: a) number of the individual; b) popular and scientific name, if possible; c) diameter at breast height in centimeters; d) total height in meters.

\section{Collection and identification of botanical ma- terial}

In each plot, unheard of species were collected, and when necessary, not unheard of species with insufficiency of material for a perfect identification. Collections were carried out in the insides as well as the circumferences of the plots. The collection and herborization of reproductive and/ or vegetable botanical material followed specific methodology recommended by Fidalgo \& Bononi (1984). The identification of the botanical material was initially carried out by the Department of Biology of the Federal University of Ceará, UFC, following the classic taxonomical standards, i.e. with a basis in floral morphological characters and using a variety of examples whenever possible. The determinations were done with analytical keys and comparisons with materials deposited in the local herbarium. In the absence of these resources, the material was sent to other specialists for identification.

\section{Organization of vegetation}

Each type of vegetation differs from others in function of its combination of attributes and characteristics. Within these attributes is the organization which can be approached in two distinct ways (Rollet, 1978, apud Rodal, 1992): architectural organization or as all individuals in vegetation are organized, independently of the species to which they belong; structural organization or as the populations are organized in 
vegetation. In order to characterize the architectural organization of the areas investigated, (1) a distribution of the individuals by height and diameter, presented with histograms with left closed intervals and right open intervals of $2 \mathrm{~m}$ and $6 \mathrm{~cm}$, respectively and (2) a quantification of the total density, total dominance, average diameter and height were carried out. To characterize the structural organization, the structure of abundance and size were analyzed. The following structural descriptions, parameters or phytosociological variables were quantified in relative values to determine the structure of abundance (Mueller-Dombois \& Ellenberg, 1974; Matteucci \& Colma, 1982): density, frequency, dominance and the respective value of importance (VI). Graphics were designed for the height and diameter where only the sample populations with at least 12 individuals common to the areas compared were included in the graphics to determine the structure of size. Finally, the architectural and structural organization of the sample Areas 1 and 2 were compared, considering the histograms, graphics and the structural descriptions cited.

\section{Floral similarity}

To determine the floral similarity between the observed areas, Sorensen indices were used (Matteucci \& Colma, 1988) for binary data (qualitative) and Morisita (Felfili et al., 1993) for quantitative data, based on the presence/absence and the abundance of species, respectively.

\section{Phytodiversity}

To estimate the diversity of arboreal species in Areas 1 and 2, the Shannon index (H') was calculated, accompanied by the respective evenness measure (E) (Stiling, 1996), using the neperian logarithm. The values of the Shannon diversity index vary from 0 to 1.0. For calculations of diversity indices as well as similarity, and general processing, FITOPAC (Shepherd, 1995) was used.

\section{RESULTS AND DISCUSSION}

\section{Architecture of abundance and size}

The absolute values observed evidenced marked architectural differences between Area 1 and 2 (Table 1). The total density verified for Area 1 was $91.2 \%$ greater than Area 2, the total domi- nance, $72.4 \%$ greater and the average height $28.8 \%$ greater. Area 2 was only greater than Area 1 in average diameter, this being $8.8 \%$ greater. The relative distribution of sample individual by diameter class in Areas 1 and 2 also showed differences, presenting similarities only with respect to a higher concentration of trees in the $5-11 \mathrm{~cm}$ diameter class (Fig. 1).

Aside from this class, the differences between the two areas were visible. Area 1 presented a scaled reduction of trees due to a diametric increase and a larger diversity of diameters, starting small $(5 \mathrm{~cm})$ to large $(65 \mathrm{~cm})$. Area 2 in turn showed an increase in the number of trees in the $17-23 \mathrm{~cm}$ class, a diametric diversity $50 \%$ smaller (only 5 classes) and a maximum diameter limited to the 29-35 cm class.

Finally, the absolute and relative distributions of the number of individuals shown by height classes in Areas 1 and 2 also presented differences (Fig. 2). Area 1 showed a greater diversity of heights, varying from 4 to $23 \mathrm{~m}$, tallest individuals (21-23 m) and a larger concentration of its trees in the 7 to $11 \mathrm{~m}$ range. Area 2 in turn, with a higher concentration of its individuals $(38 \%)$ in the 5$7 \mathrm{~m}$ range, presented less diversity in sizes (4 to $15 \mathrm{~m})$, smaller maximum height (13-15 m) and showed relative superiority in the smallest height class.

However, one can also observe many similarities between the areas: 1) the lack of formation of landings which could evidence and define a clear stratification, 2) the treetops are distributed along an average vertical space and above the forest without any definite standard, resulting in a semi-compact, monostratified arboreal cover, predominantly microfanerophytic by Raunkiaer classification adapted to Brazilian conditions (Raunkiaer, 1934, apud IBGE, 1992) and 3) an irregular and sinuous canopy resulting from sparsely emerging trees of differentiated heights.

Observing the value of 873 trees, $9.7 \mathrm{~m}^{2}$ of horizontal physical space occupied and $2.16 \mathrm{~m}$ more of average height observed in Area 1 in relation to Area 2 (Table 1) and visualizing the Figs. 1 and 2, it can be deduced that even with more than 20 years since the deforestation of Area 2, as well as being fallow, the quantitative arboreal recomposition and reoccupation of horizontal and vertical physical space did not equal that of Area 1. 
TABLE 1

Total Density (DT), Total Dominance (DoT), Average Diameter (Dx), Standard Deviation (ds) and Average Height $(\mathrm{Hx})$ of tree species $(\mathrm{DBH} \geq 5 \mathrm{~cm})$ selected in Areas 1 and 2.

\begin{tabular}{|c|c|c|c|c|}
\hline Areas & DT & DoT & Dx $\pm \mathbf{d s}$ & Hx $\pm \mathbf{d s}$ \\
\hline & (ind/ha) & $\left(\mathbf{m}^{2} / \mathbf{h a}\right)$ & $(\mathbf{c m})$ & $(\mathbf{m})$ \\
\hline 1 & 1830 & 23.1 & $10.77 \pm 6.7$ & $9.65 \pm 3.34$ \\
\hline 2 & 957 & 13.4 & $11.72 \pm 6.4$ & $7.49 \pm 2.14$ \\
\hline
\end{tabular}
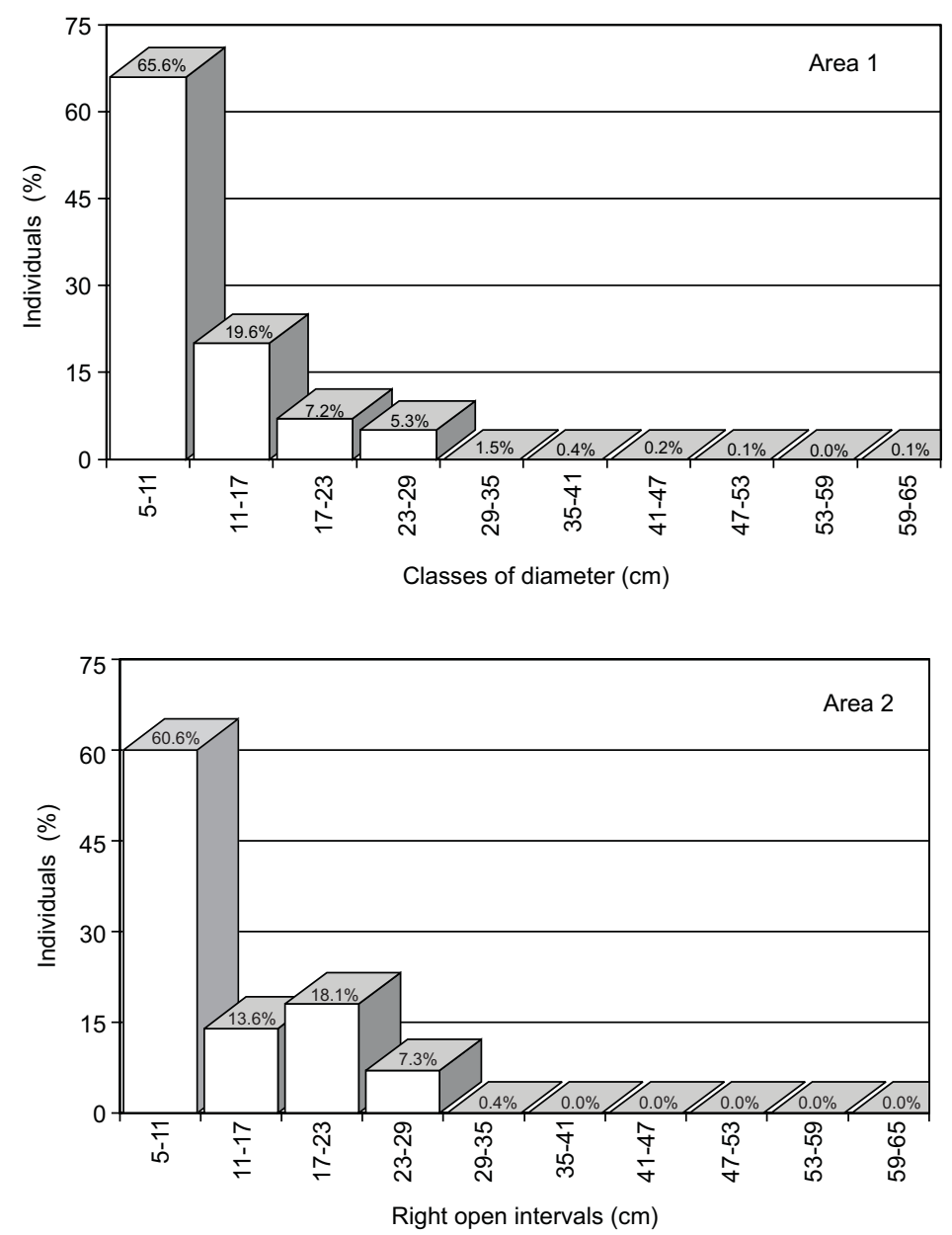

Fig. 1 - Relative distribution of the number of sample individuals by classes of diameter in Areas 1 and 2.

This tardiness in the architectural equality between the two areas among the vegetation cover investigated can be attributed to a possible wearing out of some property of the soil which disfavored the natural process of reoccupation, which in function of the contiguity of the areas should have been guaranteed by the replacement of the biological material coming from the preserved Area 1.

The slightly larger average diameter in Area 2 was related to the lack of necessity, verified in many trees to have to compete aggressively for light. 

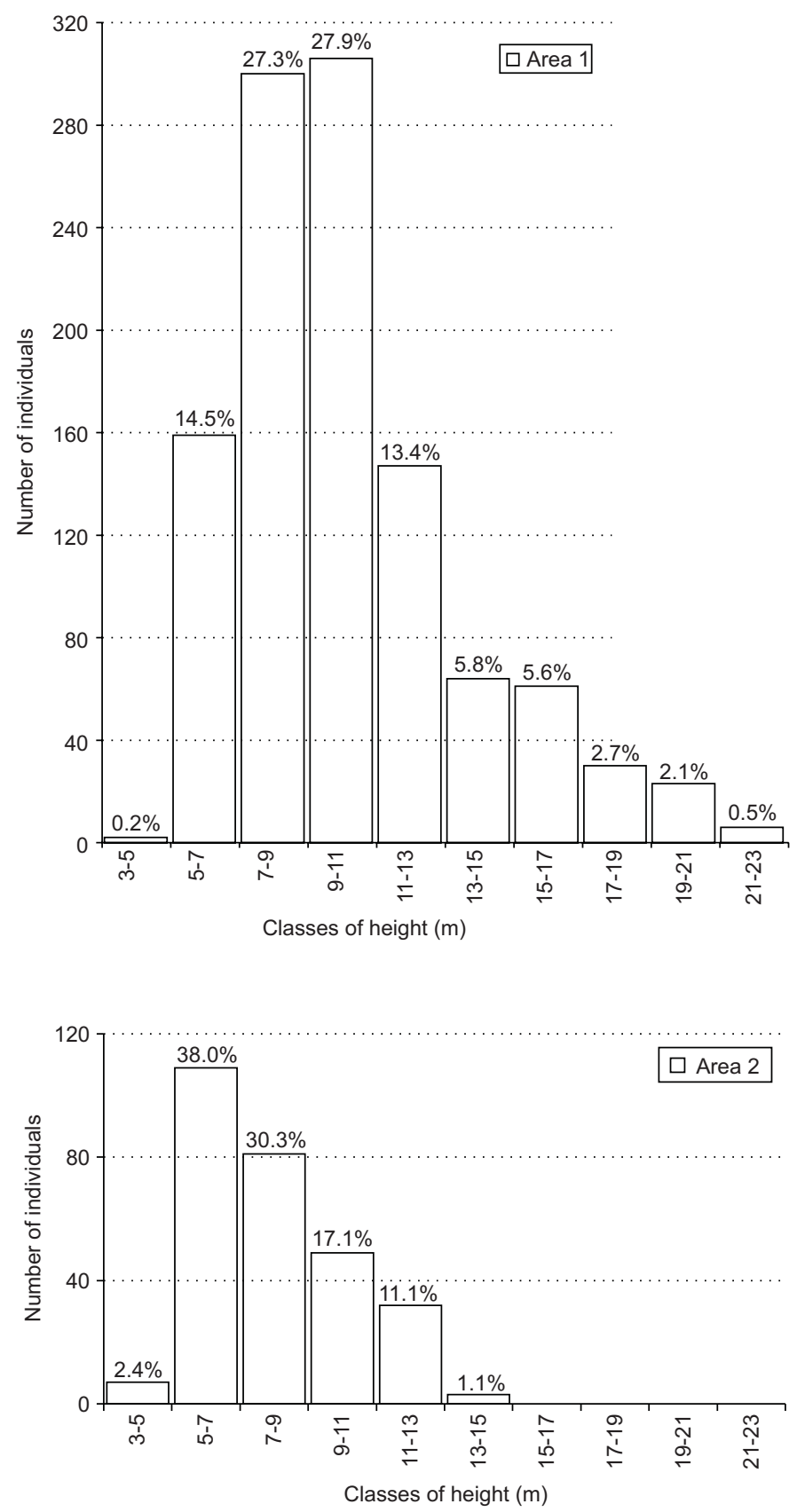

Fig. 2 - Absolute and relative distribution of the number of sample individuals by classes of height in Areas 1 and 2.

The availability of horizontal physical space between trees minimized the effects of etiolation, a commonly phenomenon observed in densely populated areas. The combination of climatic, edaphic and topographical factors throughout time bestowed a peculiar environment where according to Budowski (1963) a larger density of individuals of few species with small trunk diameters would have been expected. However, intense rains on an uncovered soil in a rough land selected species and 
reduced the number of individuals with the removal of propagule on the soil. At the same time, the verified inferior average height of the trees in this same area can also be related to the availability of physical space and abundant light, permitting greater energetic investment in lateral branches and trunks.

From the architectural point of view, two possible reasons for the resulting forest cover can be suggested starting from an accentuated deforestation followed by agricultural use of the soil as exemplified in Area 2: (1) The emergence and establishment of a new vegetational architecture characterized by being more open and smaller, or (2) now new architecture would be established, and a present vegetation cover still in process of succession of a secondary forest where the architectural equality would be attained in a longer period of time. Initially the first appears to prevail. The emergence of new forest architectures as a result of environmental degradation is possible as cited by Furley \& Ratter (1988) for the cerradão. Also Gubert-Filho (1993) elaborated a system of forest classification defining diverse forest typologies resulting from anthropic actions. Nevertheless, 25 years is a relatively short period of time in nature for diagnostics and prognostics, and a wait for more evidence is a more prudent attitude.

\section{Structure of Abundance}

The values of the tables of this item were processed electronically and the tables built organizing the species by decreasing order of their VI's. In spite of the controversy over their real ecological significance, this parameter served as a base for presentation of the results. The value of importance (VI) reveals the ecological importance relative to each species in each sample and is useful for separating different forest types as well as relating them to environmental factors (Habeck, 1968, apud Martins, 1991).

Approximately $50 \%$ of the value of importance (VI) in Area 1 concentrates on only 5 species: Myrcia multiflora, Byrsonima sericea, Clusia nemorosa, Casearia guianensis and Stryphnodendron purpureum (Table 2). In Area 2 in the same way: Stryphnodendron purpureum, Vismia guaramirangae, Inga bahiensis, Cecropia palmata and Miconia albicans (Table 3). Within the above mentioned species the Stryphnodendron purpureum stands out due to the fact that it is a member of both of the groups of five species with the largest VI in the two areas, and because it presents the largest VI in Area 2. This last observation indicates a rustic species of easy adaptation, allowing its use in degraded neighboring areas that suffer from similar human anthropic activities.

In the remaining species of Area 1, i.e., those not included in the group with the largest VI, a group made up of 10 species was found (24\% of the total shown) with a maximum of two individuals shown (Table 2).

Within these species, two labeled as unknown and popularly known as farinha seca and cidreira, although conceptually not considered as rare species according to Hubbell \& Foster (1983), brought about the urgent need to preserve this area until other scientific work can be done to explain their taxonomy, rarity, endemism and risk of extinction. In relation to unknown species 4 (sabiá) and 5 (bico de uru) the condition of rarity and taxonomy were removed after the conclusion of this project, however, the unknown species 2 (casquim) continued unidentified.

Analyzing Table 4 the following aspects in relation to the families shown in Areas 1 and 2 were observed: Area 1 showed 25 families (one unknown), thirteen more than Area 2; only the Cecropiaceae documented in Area 2, was absent in this area; The Myrtaceae and the Mimosaceae contributed most to the species richness with 4 species each. Nevertheless the Myrtaceae stood out as the most important structural family because it contained the highest number of individuals, corroborating the presence of the Atlantic Forest in the State of Ceará. According to Negrelle (1995) the Myrtaceae family has a representation and diversity all along the distribution strip of the Atlantic Forest. In Area 2, 12 families (one unknown) were counted. The Mimosaceae was the most important, contributing 65 individuals distributed in 5 species. The dominance of the Mimosaceae family is most associated with the caatingas (Rodal, 1992), vegetation which grows on lowlands of low fertility and with hydric limitations. The dominance of this family can be indicating empirically edaphic conditions similar to those of Area 2. 
TABLE 2

Arboreal species (DBH $\geq 5 \mathrm{~cm}$ ) selected (Area 1) in decreasing order of VI and their respective phytosociological parameters: Number of individuals (ne); Relative Density (DeR); Relative Frequency (FeR); Relative Dominance (DoR); Value of Importance (VI).

\begin{tabular}{|c|c|c|c|c|c|c|}
\hline Species & Family & ne & DeR & FeR & DoR & VI \\
\hline Myrcia multiflora DC. & Myrtaceae & 208 & 18.94 & 7.43 & 15.20 & 41.57 \\
\hline Byrsonima sericea DC. & Malpighiaceae & 121 & 11.02 & 7.43 & 21.82 & 40.26 \\
\hline Clusia nemorosa G. Mey. & Clusiaceae & 147 & 13.39 & 7.43 & 14.20 & 35.01 \\
\hline Casearia guianensis Urb. & Flacourtiaceae & 99 & 9.02 & 4.95 & 2.44 & 16.41 \\
\hline Stryphnodendron purpureum Ducke & Mimosaceae & 27 & 2.46 & 2.97 & 10.95 & 16.38 \\
\hline Erythroxylum citrifolium St. Hil. & Erythroxylaceae & 46 & 4.19 & 6.19 & 4.64 & 15.02 \\
\hline Byrsonima crispa Juss. & Malpighiaceae & 45 & 4.10 & 5.45 & 3.74 & 13.29 \\
\hline Myrcia rostrata DC. & Myrtaceae & 59 & 5.37 & 4.70 & 2.60 & 12.68 \\
\hline Protium heptaphyllum (Aubl.) March. & Burseraceae & 40 & 3.64 & 5.69 & 1.89 & 11.22 \\
\hline Miconia albicans Triana & Melastomataceae & 45 & 4.10 & 3.96 & 0.99 & 9.05 \\
\hline Rapanea guianensis Aubl. & Myrsinaceae & 34 & 3.10 & 3.47 & 1.94 & 8.50 \\
\hline Xylopia sericea St. Hil. & Annonaceae & 28 & 2.55 & 3.22 & 2.42 & 8.19 \\
\hline Buchenavia capitata Eichl. & Combretaceae & 12 & 1.09 & 2.72 & 4.21 & 8.03 \\
\hline Desconhecida 2 (casquim*) & & 21 & 1.91 & 3.22 & 2.63 & 7.77 \\
\hline Myrcia prunifolia DC. & Myrtaceae & 26 & 2.37 & 4.21 & 1.05 & 7.63 \\
\hline Jacaranda heteroptila Bur. \& Schum. & Bignoniaceae & 18 & 1.64 & 2.97 & 2.55 & 7.16 \\
\hline Nectandra mollis Nees & Lauraceae & 18 & 1.64 & 3.47 & 1.85 & 6.96 \\
\hline Simarouba amara Aubl. & Simaroubaceae & 23 & 2.09 & 3.22 & 0.92 & 6.23 \\
\hline Vismia guaramirangae Hub. & Clusiaceae & 7 & 0.64 & 1.73 & 0.33 & 2.70 \\
\hline Manilkara rufula Miq. & Sapotaceae & 7 & 0.64 & 1.73 & 0.31 & 2.68 \\
\hline Guazuma ulmifolia Lam. & Sterculiaceae & 7 & 0.64 & 1.73 & 0.22 & 2.59 \\
\hline Guarea tuberculata Vell. & Meliaceae & 5 & 0.46 & 1.24 & 0.22 & 1.91 \\
\hline Copaifera cearensis Hub. & Caesalpiniaceae & 5 & 0.46 & 0.99 & 0.13 & 1.57 \\
\hline Spondias lutea $\mathrm{L}$. & Anacardiaceae & 5 & 0.46 & 0.99 & 0.10 & 1.54 \\
\hline Albizia polycephala (Benth.) Killip & Mimosaceae & 3 & 0.27 & 0.74 & 0.30 & 1.32 \\
\hline Sapium lanceolatum Huber & Euphorbiaceae & 3 & 0.27 & 0.74 & 0.25 & 1.26 \\
\hline Garcinia gardneriana Pl. \& Tr. & Clusiaceae & 4 & 0.36 & 0.74 & 0.09 & 1.19 \\
\hline Artocarpus integrifolia $\mathrm{L}$. & Moraceae & 3 & 0.27 & 0.50 & 0.35 & 1.12 \\
\hline Desconhecida 1 (farinha seca*) & & 2 & 0.18 & 0.50 & 0.34 & 1.02 \\
\hline Ficus calyptroceras Miq. & Moraceae & 2 & 0.18 & 0.50 & 0.33 & 1.01 \\
\hline Tabebuia serratifolia (Vahl.) Nich. & Bignoniaceae & 3 & 0.27 & 0.50 & 0.21 & 0.98 \\
\hline Guapira opposita (Vell.) Reitz. & Nyctaginaceae & 3 & 0.27 & 0.50 & 0.11 & 0.88 \\
\hline Inga bahiensis Benth. & Mimosaceae & 2 & 0.18 & 0.50 & 0.16 & 0.83 \\
\hline Coutarea hexandra (Jacqp.) H. Schum & Rubiaceae & 3 & 0.27 & 0.50 & 0.04 & 0.81 \\
\hline Syzygium jambos (L.) Alstron & Myrtaceae & 2 & 0.18 & 0.50 & 0.06 & 0.74 \\
\hline Desconhecida 3 (cidreira*) & & 2 & 0.18 & 0.50 & 0.05 & 0.73 \\
\hline Zanthoxylum rhoifolium Lam. & Rutaceae & 2 & 0.18 & 0.50 & 0.04 & 0.72 \\
\hline Desconhecida 4 (sabiá*) & & 3 & 0.27 & 0.25 & 0.20 & 0.72 \\
\hline
\end{tabular}

* vernacular 
TABLE 3

Tree species (DBH $\geq \mathbf{5} \mathrm{cm}$ ) selected (Area 2) in decreasing order of VI and their respective phytosociological parameters: Number of individuals (ne); Relative Density (DeR); Relative Frequency (FeR); Relative Dominance (DoR); Value of Importance (VI).

\begin{tabular}{|c|c|c|c|c|c|c|}
\hline Species & Family & ne & DeR & FeR & DoR & VI \\
\hline Stryphnodendron purpureum Ducke & Mimosaceae & 25 & 8.71 & 8.70 & 22.26 & 39.67 \\
\hline Vismia guaramirangae Hub. & Clusiaceae & 53 & 18.47 & 10.87 & 7.54 & 36.87 \\
\hline Inga bahiensis Benth. & Mimosaceae & 18 & 6.27 & 8.70 & 20.90 & 35.87 \\
\hline Cecropia palmata Willd. & Cecropiaceae & 21 & 7.32 & 5.80 & 12.42 & 25.53 \\
\hline Miconia albicans Triana & Melastomataceae & 37 & 12.89 & 8.70 & 3.05 & 24.63 \\
\hline Zanthoxylum rhoifolium Lam. & Rutaceae & 31 & 10.80 & 10.14 & 3.18 & 24.13 \\
\hline Croton floribundus Spreng. & Euphorbiaceae & 16 & 5.57 & 7.25 & 7.30 & 20.12 \\
\hline Xylopia sericea St. Hil. & Annonaceae & 17 & 5.92 & 7.25 & 5.87 & 19.04 \\
\hline Inga marginata Willd. & Mimosaceae & 6 & 2.09 & 4.35 & 7.69 & 14.13 \\
\hline Myrcia prunifolia DC. & Myrtaceae & 12 & 4.18 & 5.07 & 1.05 & 10.30 \\
\hline Albizia polycephala (Benth.) Killip & Mimosaceae & 8 & 2.79 & 3.62 & 2.22 & 8.64 \\
\hline Byrsonima sericea DC. & Malpighiaceae & 8 & 2.79 & 2.90 & 0.94 & 6.63 \\
\hline Desconhecida 1 & & 4 & 1.39 & 2.90 & 2.30 & 6.59 \\
\hline Pithecellobium trapezifolium Benth. & Mimosaceae & 8 & 2.79 & 2.90 & 0.87 & 6.56 \\
\hline Copaifera cearensis Hub. & Caesalpiniaceae & 6 & 2.09 & 3.62 & 0.61 & 6.32 \\
\hline Myrcia multiflora DC. & Myrtaceae & 8 & 2.79 & 2.17 & 0.97 & 5.93 \\
\hline Miconia sp. & Melastomataceae & 6 & 2.09 & 2.90 & 0.50 & 5.49 \\
\hline Jacaranda heteroptila Bur. \& Schum. & Bignoniaceae & 3 & 1.05 & 2.17 & 0.33 & 3.54 \\
\hline Total/18 & 12 & 287 & 100 & 100 & 100 & 300 \\
\hline
\end{tabular}

\section{Structure of size}

In considering only populations with at least 12 individuals (minimum number of mother trees in a population capable of guaranteeing a reasonable genetic diversity, Kageyama et al., 1992) and in comparing (diameters and heights) within these species only those common in Areas 1 and 2 (Fig. 3), it was verified that while the heights of the species Miconia albicans, Myrcia prunifolia, Stryphnodendron purpureum and Xylopia sericea exemplified a tendency to be larger in Area 1 (also observed in the architectural approach), the diameter in no way revealed that it could also indicate a standard or a tendency, i.e., no diametric supremacy appeared to have occurred in one area over another. This lack of diametric tendency appears to be related to the existence of marks in different successive time periods in the areas, not forming forests homogeneous in age, but rather a forest mosaic in constant transformation.

\section{Similarity}

The forest surveys carried out in Areas 1 and 2 and submitted to comparative binary and quantitative treatment (presence/absence) of the species, allowed the evaluation of the impact of the deforestation which occurred in Area 2. With reference to deforestation, the results of the binary $(60 \%)$ and quantitative $(36 \%)$ similarity clearly showed the damage caused to the forest. In addition to the 28 less species in the formerly deforested area and a current densely distinct floristic composition, three new species established themselves in the area: Cecropia palmata, Croton floribundus and Inga marginata. The arboreal Cecropia palmata which occurs naturally in the mountains, appears to be a strong indicator of areas which suffer intense human activity since it occurs abundantly and in a general way in Area 2 and in adjacent areas which have undergone visibly similar damaging actions. 
TABLE 4

Families selected (Areas 1 and 2) in decreasing order of ne: Number of individuals (ne); Number of species (nsp).

\begin{tabular}{|c|c|c|c|c|c|c|c|}
\hline Family/A1 & ne & nsp & $\%$ nsp & Family/A2 & ne & nsp & $\%$ nsp \\
\hline Myrtaceae & 295 & 4 & 9.52 & Mimosaceae & 65 & 5 & 27.78 \\
\hline Malpighiaceae & 166 & 2 & 4.76 & Clusiaceae & 53 & 1 & 5.56 \\
\hline Clusiaceae & 158 & 3 & 7.14 & Melastomataceae & 43 & 2 & 11.11 \\
\hline Mimosaceae & 34 & 4 & 9.52 & Cecropiaceae & 21 & 1 & 5.56 \\
\hline Flacourtiaceae & 99 & 1 & 2.38 & Rutaceae & 31 & 1 & 5.56 \\
\hline Erythroxylaceae & 46 & 1 & 2.38 & Euphorbiaceae & 16 & 1 & 5.56 \\
\hline Burseraceae & 40 & 1 & 2.38 & Annonaceae & 17 & 1 & 5.56 \\
\hline Desconhecida & 30 & 5 & 11.90 & Myrtaceae & 20 & 2 & 11.11 \\
\hline Melastomataceae & 47 & 2 & 4.76 & Malpighiaceae & 8 & 1 & 5.56 \\
\hline Myrsinaceae & 34 & 1 & 2.38 & Desconhecida & 4 & 1 & 5.56 \\
\hline Annonaceae & 28 & 1 & 2.38 & Caesalpiniaceae & 6 & 1 & 5.56 \\
\hline Combretaceae & 12 & 1 & 2.38 & Bignoniaceae & 3 & 1 & 5.56 \\
\hline Bignoniaceae & 21 & 2 & 4.76 & & & & \\
\hline Lauraceae & 18 & 1 & 2.38 & & & & \\
\hline Simaroubaceae & 23 & 1 & 2.38 & & & & \\
\hline Sapotaceae & 7 & 1 & 2.38 & & & & \\
\hline Sterculiaceae & 7 & 1 & 2.38 & & & & \\
\hline Meliaceae & 5 & 1 & 2.38 & & & & \\
\hline Moraceae & 5 & 2 & 4.76 & & & & \\
\hline Caesalpiniaceae & 5 & 1 & 2.38 & & & & \\
\hline Anacardinaceae & 5 & 1 & 2.38 & & & & \\
\hline Rutaceae & 4 & 2 & 4.76 & & & & \\
\hline Euphorbiaceae & 3 & 1 & 2.38 & & & & \\
\hline Nyctaginaceae & 3 & 1 & 2.38 & & & & \\
\hline Rubiaceae & 3 & 1 & 2.38 & & & & \\
\hline Total $/ 25$ & 1098 & 42 & 100 & Total/12 & 287 & 18 & 100 \\
\hline
\end{tabular}

The quality of the indicator here signifies pioneerism in the successional process and this attribute is also commonly cited in literature (Gandolfi, 1991) for this species. The Croton floribundus which appears to proceed from lower areas or the western slope of the mountain range (drier areas) was not as generalized as the Cecropia palmata, not having been observed in abundance or characterizing adjacent areas physionomically. Finally, the Inga marginata was introduced in the past in order to provide shade for the coffee plantation and established itself satisfactorily as well as the Inga bahiensis. In spite of possible sampling, processing and interpretation errors, the result that determined 28 fewer species in Area 2 (deforested), appears to be sufficient to caution about the risks of survival of the local flora and fauna in the near future as this local model of development continues.

\section{Phytodiversity}

In Area 1 (0.6 ha) 1098 live individuals belonging to 42 species distributed among 25 families were registered and in Area 2 (0.3 ha), 287 individuals belonging to 18 species and 12 families (Table 2 and 3). Five species labeled as unknown were not identified, being included in a single family denominated as Unknown. 

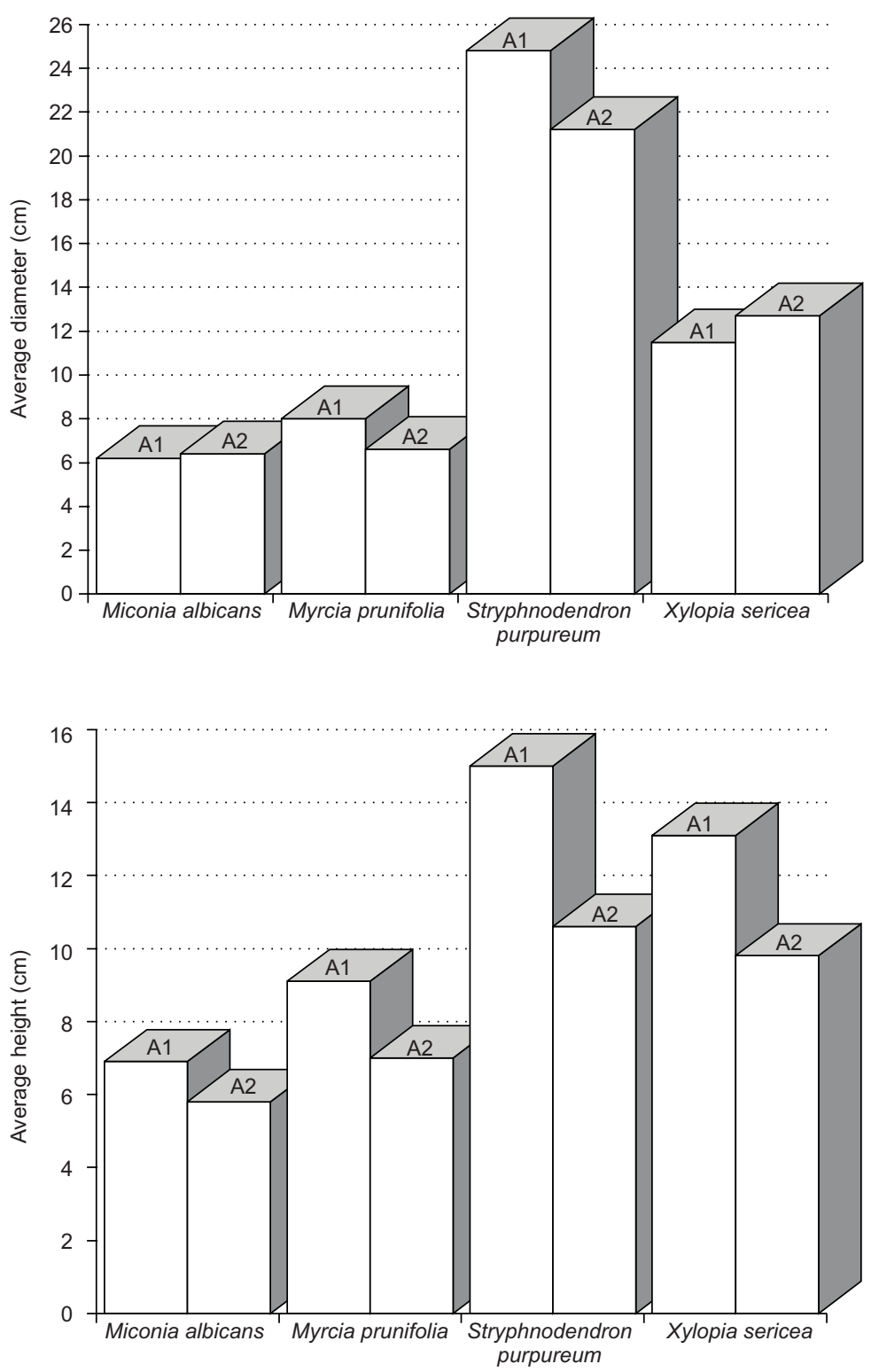

Fig. 3 - Average diameters and heights of 4 common arboreal species in Areas 1 and 2 with at least 12 sample specimens.

In comparing Areas 1 and 2 according to their floristic richness or simply by the total number of species counted (McIntosh, 1967, apud Stiling, 1996), 57\% less richness (24 species) was verified in Area 2. At the same time, Shannon's diversity indices pointed to a inferior diversity in Area 2, even when all the species were given equal abundance (E) (Table 5). According to Gentry (1988) the size of the sample significantly influences the index of diversity obtained, however, this loss of floristic richness did not occur exclusively due to the 50\% smaller size of the sample Area 2, since even spatially equaling the sample areas involved, i.e. doubling the area size of Area 2 and proportionally inferring an increase in the number of species for this area, the hypothetical value obtained (36 species) would also be inferior to that of Area 1. 
TABLE 5

Shannon's indices of diversity (H'), maximum diversity $\left(\mathrm{H}_{\max }\right)$ and Evenness $(\mathrm{E})$ of the sample Areas 1 and 2.

\begin{tabular}{|c|c|c|c|}
\hline Sample area & $\mathbf{H}^{\prime}$ & $\mathbf{H}_{\max }$ & $\mathbf{E}$ \\
\hline 1 & 2.85 & 3.74 & 0.76 \\
\hline 2 & 2.60 & 2.89 & 0.90 \\
\hline
\end{tabular}

However, this reduction in phytodiversity could be principally related to a manifestation of the soil to the damage suffered where hypothetically the neighboring areas could subsidize the damaged areas, thus a greater phytodiversity could be guaranteed.

\section{REFERENCES}

BUDOWSKI, G., 1963, Forest succession in tropical lowlands. Turrialba, 13(1): 42-44.

FELFILI, J. M., SILVA-JUNIOR, M. C., RESENDE, A. V., MACHADO, J. W. B., WALTER, B. M. T., SILVA, P. E. N. \& HAY, J. D., 1993, Análise comparativa da florística e fitossociologia da vegetação arbórea do cerrado sensu stricto na chapada Pratinha, DF, Brasil. Acta Bot. Bras., 6(2): $27-46$.

FIDALGO, O. \& BONONI, V. L. R., 1984, Técnicas de coleta, preservação e herborização de material botânico. Instituto de Botânica, São Paulo, 106p.

FIGUEIREDO, M. A., LIMA-VERDE, L. W. \& PAULA, L., 1995, A Mata Atlântica no Ceará. Anais 6o Congresso Nordestino de Ecologia, João Pessoa, pp. 20-25.

FUNCEME, 1994, Geossistemas e potencialidades dos recursos naturais: Serra de Baturité e áreas sertanejas periféricas. DETEC, Fortaleza, 111p.

FURLEY, P. A. \& RATTER, J. A., 1988, Soil resources and plant communities of central Brazilian cerrado and their development. J. of Biogeography, 15: 97-108.

GANDOLFI, S., 1991, Estudo florístico e fitossociológico de uma floresta residual na área do aeroporto internacional de São Paulo, município de Guarulhos, SP. Dissertação de Mestrado, Unicamp, Campinas.

GENTRY, A. H., 1988, Changes in plant community diversity and floristic composition on enviromental and geographical gradients. Annals of the Missouri Botanical Garden, 75(1): 1-34.

GUBERT-FILHO, A., 1993, A tipologia florestal determinada pelo fator antrópico. Anais I Congresso Florestal Panamericano, Curitiba, pp. 1-5.
HUBBELL, S. P. \& FOSTER, R. B., 1983, Diversity of canopy trees in a neotropical forest and implications for conservation. In: S. L. SUTTON, T. C. WHITMORE \& A. C. CHADWICK. Tropical rain forest: ecology and management. Brit Ecol. Soc. Special Pub, n. 2, Blackwell Scientific, Oxford, pp. 25-41.

IBGE, 1992, Manual técnico da vegetação brasileira. CDDI, Rio de Janeiro, 92p.

KAGEYAMA, P. Y., 1992, Recomposição da vegetação com espécies arbóreas nativas em reservatórios de usinas hidrelétricas da CESP. Série Técnica IPEF, 8(25): 30-34.

LEITE, F. A. B. \& MARQUES, J. N., 1998, Solos. In: IPLANCE, Atlas do Ceará. Fortaleza, pp. 16-17.

MARTINS, F. R., 1991, Estrutura de uma floresta mesófila. Unicamp, Campinas, 246p.

MATTEUCCI, S. D. \& COLMA, A., 1982, Metodologia para el estudio de la vegetación. Secretaría General de la OEA, Washington, D.C, 163p.

MELLER-DOMBOIS, D. \& ELLENBERG, H., 1974, Aims and methods of vegetation ecology. John Wiley \& Sons, New York, 574p.

NEGRELLE, R. R. B., 1995, Composição florística, estrutura fitossociológica e dinâmica de regeneração da Floresta Atlântica na reserva Volta Velha, mun. Itapoá, SC. Tese de Doutorado, UFSCar, São Carlos.

NIMER, E., 1989, Climatologia do Brasil. IBGE/CDDI, Rio de Janeiro, 421p.

PNUD/FAO/IBAMA/SEMACE, 1994, Mapeamento da cobertura florestal nativa lenhosa do Estado do Ceará. SEMACE, Fortaleza, 47p.

RODAL, M. J. N., 1992, Fitossociologia da vegetação arbustivo-arbórea em quatro áreas de caatinga em Pernambuco. Tese de Doutorado, Unicamp, Campinas.

SHEPHERD, G. J., 1995, FITOPAC 1. Manual do usuário. Departamento de Botânica, Unicamp.

STILING, P. D., 1996, Ecology. Theories and Applicacions. $2^{\text {nd }}$ ed., Prentice-Hall, New Jersey, 539p. 